\title{
STUDIES ON THE MOLLUSCAN FAECES (III)
}

$\operatorname{AUTHOR}(\mathrm{S})$ :

Arakawa, Kohman Y.

\section{CITATION:}

Arakawa, Kohman Y.. STUDIES ON THE MOLLUSCAN FAECES (III).

PUBLICATIONS OF THE SETO MARINE BIOLOGICAL LABORATORY 1968, 16(2): $127-139$

ISSUE DATE:

1968-09-25

URL:

http://hdl.handle.net/2433/175539

RIGHT: 


\title{
STUDIES ON THE MOLLUSCAN FAECES (III)
}

\author{
KoHMAN Y. ARAKAWA \\ Hiroshima Fisheries Experiment Station \\ Tomokura, Ondo-cho, Aki-gun, Hiroshima
}

With Plates XVI-XVII and 4 Text-figures

The present paper is a record of observations on the molluscan faecal pellets of fourty species inclusive of thirty-three gastropods, three polyplacophores, two scaphopods and two cephalopods. They were all collected from various parts of Chiji-wa Bay on the western coast of Kyushu Island and its adjacent regions.

Before passing into the description, I wish to express my cordial thanks to Dr. Taiji KIKUCHI, Mr. Akio TAKI and to other members of the Amakusa Marine Biological Laboratory, Kyushu University, for their kind help and facilities given to me during my work at the Laboratory. Thanks are also due to Dr. Takasi Tokioka for his editorial advices and criticisms.

\section{Material}

Listed below are the scientific names of molluscs examined in this study.

\section{POLYPLACOPHORA}

Mopaliidae

Cryptoplaciidae

Ischnochitonidae

\section{GASTROPODA}

Fissurellidae

Patellidae

Trochidae

Stomatellidae

Neritidae

Turritellidae

Potamididae
1. Placiphorella sp.

2. Cryptoplax japonica PILSBRY ケムシヒザラガイ

3. Ischnochiton comptus forma isaoi Iw. TAKI ホソウスヒザラガイ

4. Macroschisma dilatata A. AdAMS ヒラスカシガイ

5. Scutus sinensis (BLAINville) オトメガサ

6. Cellana eucosmia PILs. ベッコオザラ

7. Conotalopia musiva (Gould) ヒナシタダミ

8. Hybochelus lyrata (PILs.) アシヤガイ

9. Stomatella lintricula (A. AD.) ウスヒメアワビ

10. ?Clithon sowerbyanus (RÉGLUZ) カノコガイ

11. Kurosioia cingulifera (SowERBY) ヒメキリガイダマシ

12. ?Cerithidea ornata A. AD. シマヘナタリ

Publ. Seto Mar. Biol. Lab., XVI (2), 127-139, 1968. (Article 11) 

Cerithiidae
13. Proclava kochi (PhulIPPI) カニモリガイ
Calyptraeidae
14. Crepidula gravispinosa KuRODA \& HABE アワブネ
15. Syphopatella walshi (REEVE) ヒラフネガイ
Strombidae
16. Donaxander vittatus japonicus (RvE.) シドロ
Eulimidae
17. Niso hizenensis Kur. \& HAB. ヘソアキゴウナ
Eratoidae
18. Praterato callosa (AD. \& RvE.) ザクロガイ
Cypraeidae
19. Evenaria japonica (SGHILDER) メダカラガイ
20. Erosaria magistra (MELviLL) ハッユキダカラ
Muricidae
21. Cronia margariticola (BRODERIP) ウネレイシダマシ
22. Ergalatax.contractus (RVE.) ヒメヨオラク
Rapidae
23. Latiaxis pagodus (A. AD.) ヒメカセン
Pyrenidae
24. Pyrene testudinaria tylerae (GRIfFith \& Pidgeon) マッムシガイ
Nassariidae
25. Niotha livescens (РнI.) ムシロガイ
26. Reticunassa fraterculus (DUNKER) クロスヂムシロ
Buccinidae
27. Pisania ferrea (Rve.) イソニナ
Mitridae
28. Strigatella scutulata (GMELIN) ヤタテガイ
Olividae
29. Baryspira albocallosa (LISCHKE) リュウグウボタル
Terebridae
30. Noditerebra evoluta (DEshayes) イワカワトクサ
Acteonidae
31. Strigopupa strigosa (GoulD) コシイノミガイ
Scaphanderidae
32. Acteocina decorata (PrLs.) ツララガイ
Siphonariidae
33. Siphonaria sirius PrLs. キクノハナガイ
Dorididae
34. Glossodoris festiva (A. AD.) アオウミウシ
35. Homoiodoris japonica BERGH ヤマトウミウシ
Gastropteriidae
36. Gastropteron bicornutus BABA \& Tокıока アマクサウミコチヨオ
SCAPHOPODA
Dentaliidae
37. Fissidentalium vernedei (Sow.) マルッノガィ
38. Graphtacme buccinulum GouLD ヒメナガッノガイ

\section{CEPHALOPODA}
Sepiolidae
39. Sepiola sp.
Octopodiidae
40. Callistoctopus arakawai Iw. TAKI シマダコ

\section{Descriptions}

\section{Placiphorella sp.}

(PI. XVI, fig. 1; Text-fig. 1)

Pellets are oval in outline, fine in texture and dark purplish brown in colour. Occasionally, they are produced bound together in a chain. The ovoids are formed of rather coarse materials containing some spicules and other skeletal matters. The ratio length/breadth of pellets is 1.58 on an average. 
Measurements :

(Spec. No. 166)

$\begin{array}{llll}\text { Breadth of pellet }(\mathrm{mm}) & 0.13 & 0.15 & 0.18 \\ \text { Length of pellet }(\mathrm{mm}) & 0.22 & 0.24 & 0.26 \\ \text { Length/Breadth } & 1.69 & 1.60 & 1.44\end{array}$

\section{Cryptoplax japonica PILsBry}

Only the pellets partially damaged were available. The pellets may be produced in the shape of an elongate ellipsoid. The surface is unsculptured and rather coarse in texture. The colour is bright greenish brown. The breadth of the pellet from an animal $3.3 \mathrm{~cm}$ long, is $0.64 \mathrm{~mm}$.

\section{Ischnochiton comptus forma isaoi Iw. TAKI}

$$
\text { (Pl. XVI, fig. 2) }
$$

Pellets are typically ovoid with rounded ends. The colour varies from greyish white to light greyish brown, usually variegated with dull yellow patches of partially digested algal fragments. The surface is rather coarse in texture. The ratio length/ breadth of pellets is 1.81 on an average.

\begin{tabular}{cccccccccccc} 
Measurements: Size of animal & \multicolumn{8}{c}{ (Spec. No. 161) } & -1.35 & $\mathrm{~cm}$ in length. \\
Breadth of pellet & $(\mathrm{mm})$ & 0.69 & 0.55 & 0.67 & 0.66 & 0.58 & 0.67 & 0.64 & 0.60 \\
Length of pellet & $(\mathrm{mm})$ & 1.27 & 0.97 & 1.09 & 1.27 & 1.09 & 1.31 & 1.27 & 1.27 \\
Length/Breadth & & 1.84 & 1.76 & 1.63 & 1.92 & 1.88 & 1.96 & 1.98 & 2.12 \\
& & \multicolumn{6}{c}{ (Spec. No. 236) } & 0.4 & $\mathrm{~cm}$ in length. \\
B. & & 0.25 & 0.28 & 0.28 & 0.28 & 0.27 & 0.27 & 0.27 \\
L. & & 0.44 & 0.49 & 0.49 & 0.41 & 0.48 & 0.46 & 0.49 \\
L/B. & & 1.76 & 1.79 & 1.79 & 1.46 & 1.78 & 1.70 & 1.82
\end{tabular}

\section{Macroschisma dilatata A. AdAms}

Faecal rods in this species are unsculptured, circular in section, coarse in texture, and soft and loose in consistency. They are bright greenish grey in colour. They are made of gelatinous matters mixed with coarse algal fragments. Average breadth of faecal rods is $0.62 \mathrm{~mm}$ for an animal with a shell $1.1 \mathrm{~cm}$ long.

\section{Scutus sinensis (BLAINVILLE)}

$$
\text { (P1. XVI, fig. 3) }
$$

Rods are channelled on the ventral side by a single longitudinal groove. The surface of the rods is rather fine and homogeneous, but frequently chapped by numerous occasional transverse cracks. They are greyish brown in colour and formed of 
fine indeterminable particles. There is a concentration of the coarser materials towards the centre. In an animal with the shell-length 1.40 to $1.65 \mathrm{~cm}$, pellets range from $0.86 \mathrm{~mm}$ to $1.13 \mathrm{~mm}$ thick across.

\section{Cellana eucosmia PiLsBry}

Faecal rods are indistinctly marked over the surface by a left-handed spiral groove. They are usually shed carrying a large amount of viscous matter. The superficial consistency is rather coarse and loose. Pellet-colour varies from dark chocolateyellowish pink to bright greyish green. The pellet-breadth averages $0.26 \mathrm{~mm}$, for an animal with a shell $1.1 \mathrm{~cm}$ long.

\section{Conotalopia musiva (GouLd)}

$$
\text { (Pl. XVI, fig. 4) }
$$

Faecal rods have two prominent longitudinal ridges. The pellet-surface is rather coarse, soft and friable in consistency, but for the ventro-median ridges (or liver strings) where the texture is very fine and homogeneous. They are light greenish grey in colour. The pellet-breadth fluctuates between 0.13 and $0.15 \mathrm{~mm}$, for an animal with a $0.28 \mathrm{~cm}$ long shell.

\section{Hybochelus (Granata) lyrata (PILSBRY)}

(Pl. XVI, fig. 5)

Faecal rods are cylindrical in shape with a polyfoliate section. They are longitudinally cut on the surface into thirteen small ridges by the same number of parallel grooves. Each of these ridges is blurred laterally with undulate markings, except for the mid-ventral ridge or liver string which is further divided into two minor ridges by a slight median groove. The inner structure of the pellets is much complicated, with a distinct localization of food materials: the coarse materials containing sand grains and fragmentary shell pieces around the central core and the finer substances towards the periphery. They are usually soft and fragile in consistency and greenish grey in colour. The pellet-breadth for an animal with a $0.7 \mathrm{~cm}$ long shell averages $0.55 \mathrm{~mm}$.

\section{Stomatella lintricula (A. Adams)}

(Pl. XVI, fig. 6)

This species gives off the pellets of the typical trochid-type with a polyfoliate section. The dorsal and lateral surface of pellets is cut by six shallow longitudinal 
grooves into five ridges of equal size with lateral edges finely undulated, while the ventral surface is channelled by two deep longitudinal grooves and divided into three unequal ridges without any prominent surface markings. Of these three ridges, the median one is the smallest but most distinctive. The pellets are greyish brown in colour and shed usually in pieces. The pellet-breadth ranges from 0.31 to $0.35 \mathrm{~mm}$ for an animal with the shell-length of $0.3 \mathrm{~cm}$.

\section{0. ? Clithon sowerbyanus (RÉGLUz)}

Pellets of the present species are shed in a continuous rod. They are smoothly surfaced and without any external sculptures. The consistency is soft and loose. The colour is light greenish grey. Pellets shed by an animal with a $1.52 \mathrm{~cm}$ long shell average $1.04 \mathrm{~mm}$ in breadth.

\section{Kurosioia cingulifera (SOWERBY)}

$$
\text { (Pl. XVI, fig. 7) }
$$

Pellets are usually shed in a constricted rod, although frequently in ovoid pieces with truncate ends. The surface consistency is rather coarse in matured animals and fine in juveniles. The colour ranges from yellowish chocolate to light yellowish grey according to the food taken in.

\begin{tabular}{ccccccccc} 
Measurements: Size of animal & \multicolumn{9}{c}{ (Spec. No. } & 192)-1.8 & $\mathrm{cm}$ in alt. \\
Breadth of pellet pieces (mm) & 0.20 & 0.16 & 0.18 & 0.18 & 0.18 & 0.16 & 0.16 \\
Length of pellet pieces $(\mathrm{mm})$ & 0.24 & 0.22 & 0.20 & 0.20 & 0.20 & 0.18 & 0.16 \\
Length/Breadth & 1.20 & 1.38 & 1.11 & 1.11 & 1.11 & 1.13 & 1.00
\end{tabular}

(Specimen No. 211) $-2.1 \mathrm{~cm}$ in alt.

\begin{tabular}{|c|c|c|c|c|c|c|}
\hline B. & 0.27 & & 0.16 & & & \\
\hline L. & 0.31 & & 0.22 & & & \\
\hline \multirow[t]{2}{*}{$\mathrm{L} / \mathrm{B}$. } & 1.15 & & 1.38 & & & \\
\hline & (Specimen $\mathrm{N}$ & 253 & & & & \\
\hline B. & 0.12 & 0.11 & 0.08 & 0.11 & 0.16 & 0.10 \\
\hline L. & 0.17 & 0.18 & 0.20 & 0.16 & 0.28 & 0.30 \\
\hline $\mathrm{L} / \mathrm{B}$. & 1.42 & 1.64 & 2.50 & 1.45 & 1.75 & 3.00 \\
\hline
\end{tabular}

\section{2. ? Cerithidea ornata A. ADAms}

(Pl. XVI, fig. 8; Text-fig. 2)

Faecal pellets of this species are elongate fusiform and with tapered ends. The surface is coarse and somewhat sandy in appearance. They are bright olivaceous in colour. The ratio length/breadth of pellets is 9.75 on an average. 




Fig. 1. Pellets of Placiphrrella sp. Fig. 2. Pellets of ?Cerithidea ornata A. Adams. Fig. 3. Pellets of Praterato callosa (Adams \& Reeve). Fig. 4. Pellets of Callistoctopus arakawai Iw. TAKI. 
Measurements:

(Spec. No. 251)

Breadth of pellet $(\mathrm{mm})$

0.29

0.27

Length of pellet $(\mathrm{mm})$

2.55

2.91

Length/Breadth

8.72

10.78

\section{Proclava kochi (PhilipPI)}

(P1. XVI, fig. 9)

Pellets are typically ovoid. The consistency is fine, homogeneous and well consolidated. They are composed almost of fine materials containig some sand grains. The ratio length/breadth of pellets averages 1.65 .

Measurements: Size of animal (Spec. No. 188)-2.6-2.9 cm in alt.

$\begin{array}{llllll}\text { Breadth of pellet }(\mathrm{mm}) & 0.27 & 0.33 & 0.35 & 0.35 & 0.46 \\ \text { Length of pellet }(\mathrm{mm}) & 0.49 & 0.49 & 0.60 & 0.51 & 0.82 \\ \text { Length/Breadth } & 1.81 & 1.48 & 1.71 & 1.46 & 1.78\end{array}$

\section{Crepidula gravispinosa Kuroda \& HaBe}

(Pl. XVI, fig. 10)

Pellets of this species are very similar to those of the preceding species. However, in the pellets of Crepidula, one end is more obtuse than the other. The average ratio length/breadth is 1.82 .

Measurements: Size of animal (Spec. No. 137)-1.4-1.7 cm in length.

$\begin{array}{lllllllllll}\text { Breadth of pellet }(\mathrm{mm}) & 0.35 & 0.27 & 0.27 & 0.26 & 0.24 & 0.29 & 0.27 & 0.24 & 0.31 & 0.27 \\ \text { Length of pellet }(\mathrm{mm}) & 0.69 & 0.46 & 0.46 & 0.44 & 0.49 & 0.60 & 0.53 & 0.46 & 0.46 & 0.46 \\ \text { Length/Breadth } & 1.97 & 1.70 & 1.70 & 1.69 & 2.04 & 2.07 & 1.96 & 1.92 & 1.48 & 1.70\end{array}$

\section{Syphopatella walshi (REEVE)}

(Pl. XVI, fig. 11)

Pellets are normally ovoid in shape with rounded ends; one end may be a little tapered. They are, at times, produced in a short rod with constrictions. They are solid, finely and smoothly surfaced. The colour varies greatly from pale greyish green to dark chocolate or to yellowish brown. The ratio length/breadth of pellet pieces is 1.89 for the female and 1.43 for the male on an average.

\begin{tabular}{lrlllllllll} 
Measurements: Size of animal & \multicolumn{4}{c}{ (Spec. No. 139, female) $-1.8 \mathrm{~cm}$ in length. } \\
Breadth of pellet (mm) & 0.18 & 0.16 & 0.18 & 0.18 & 0.18 & 0.22 & 0.20 & 0.18 & 0.16 \\
Length of pellet $(\mathrm{mm})$ & 0.27 & 0.27 & 0.31 & 0.26 & 0.38 & 0.51 & 0.44 & 0.40 & 0.29 \\
Length/Breadth & 1.50 & 1.69 & 1.72 & 1.44 & 2.11 & 2.32 & 2.20 & 2.22 & 1.81
\end{tabular}




\begin{tabular}{ccccccccccc} 
& \multicolumn{4}{c}{ (Specimen No. } & 255 , male) & ca. $0.6 \mathrm{~cm}$ in length. \\
B. & 0.12 & 0.13 & 0.13 & 0.13 & 0.09 & 0.12 & 0.08 & 0.13 & 0.14 \\
L. & 0.19 & 0.17 & 0.18 & 0.17 & 0.14 & 0.18 & 0.12 & 0.18 & 0.18 \\
L/B. & 1.58 & 1.31 & 1.39 & 1.31 & 1.56 & 1.50 & 1.50 & 1.39 & 1.29
\end{tabular}

16. Donaxander vittatus japonicus (REEVE)

(Pl. XVII, fig. 12)

Faecal pellets are composed of small ellipsoidal or string-shaped constituents tightly combined together by mucus to form a short rod. The shape of the constituents seems to vary with the dietetic condition of the animal, from ellipsoid to filamentous rod through the state of constricted rods. The colour is greenish brown. The size of pellets voided by an animal with a $4.2 \mathrm{~cm}$ long shell is $1.5 \times 2.5 \mathrm{~mm}$ on an average.

Measurements: (Spec. No. 128)

Breadth of constituent pellets ( $\mathrm{mm}$ )

Length of the same $(\mathrm{mm})$

0.27

0.55

Length/Breadth

$\begin{array}{lllll}2.04 & 2.94 & 2.50 & 2.14 & 4.40\end{array}$

\section{Niso hizenensis Kuroda \& HaBE}

(Pl. XVII, fig. 13)

The faecal pellets are somewhat irregular in shape, and with the coarse and uneven surface. They vary in colour from dull yellow to yellowish brown or to chocolate.

$\begin{array}{cccc}\text { Measurements: Size of animal } & \text { (Spec. No. 200)-1.1-1.3 cm in alt. } \\ \text { Breadth of pellet }(\mathrm{mm}) & 0.24 & 0.20 & 0.20 \\ \text { Length } \text { of pellet }(\mathrm{mm}) & 0.40 & 0.40 & 0.33 \\ \text { Length/Breadth } & 1.67 & 2.00 & 1.65\end{array}$

\section{Praterato (Sulcerate) callosa (Adams \& ReEve)}

$$
\text { (Pl. XVII, fig. 14; Text-fig. 3) }
$$

This species produces typical ovoid pellets with rounded ends. At times, however, there may be pellets with pointed ends, or with one end more obtuse than the other end. They are somewhat coarse and loose in consistency. The colour ranges from dark brown to grey. The ratio length/breadth of pellets averages 1.89 .

\begin{tabular}{ccccccc} 
Measurements: Size of animal & \multicolumn{4}{c}{ (Spec. No. 219) } & $-0.3 \mathrm{~cm}$ in alt. \\
Breadth of pellet (mm) & 0.07 & 0.07 & 0.09 & 0.09 & 0.09 & 0.07 \\
Length of pellet (mm) & 0.20 & 0.16 & 0.16 & 0.20 & 0.15 & 0.15 \\
Length/Breadth & 2.80 & 2.29 & 1.18 & 2.22 & 1.67 & 2.14
\end{tabular}

(Specimen No. 233) $-0.4 \mathrm{~cm}$ in alt.

$\begin{array}{rllll}\text { B. } & 0.29 & 0.24 & 0.31 & 0.27 \\ \text { L. } & 0.38 & 0.44 & 0.64 & 0.46 \\ \text { L/B, } & 1.31 & 1.83 & 2.06 & 1.70\end{array}$




\section{Evenaria (Cupinota) japonica (SaHILdER)}

$$
\text { (PI. XVII, fig. 15) }
$$

Faecal rods are built of convoluted rodlets. The pellets show a distinctive variegation from place to place, according to the food constituents_cream yellow at the sites where the materials consist of fine and well-digested particles, while greyish white at the places where they are coarse and sandy. The pellets from an animal with a $1.4 \mathrm{~cm}$ long shell are $0.73 \mathrm{~mm}$ in breadth on an average and the breadth of the constituent rodlets ranges from 0.15 to $0.18 \mathrm{~mm}$.

\section{Erosaria magistra (MELVILL)}

The pellets are essentially similar to those of the preceding species. They are irregular in shape and constituted of convolved rodlet $0.18-0.33 \mathrm{~mm}$ in breadth. They are soft, friable and coarse in consistency. The colour is pale orange and variegated with light brownish black. They are composed of well-digested fine matters, probably of an animal origin. Normally, they are shed embedded in a large amount of mucoid substance.

\section{Cronia margariticola (BRODERIP)}

Faeces are discharged mingled with a large amount of mucoid matter. They are very soft, loose in consistency, without any definite shape, and greyish green in colour.

\section{Ergalatax contractus (REEve)}

Faeces of this species do not form any definite shape and light olivaceous in colour. They are usually voided in a large amount of mucus, and consist of well-digested matters mixed with some broken shell pieces.

\section{Latiaxis pagodus (A. AdAms)}

(Pl. XVII, fig. 17)

Pellets are discharged in the form of a short rod which is slightly constricted at rather short intervals. They are coarse and uneven on the surface, occasionally chapped by clefts, rather soft in consistency, and greyish green in colour. The pellets voided by an animal with a $0.7 \mathrm{~cm}$ long shell is $0.35 \mathrm{~mm}$ thick across and with constrictions at intervals of $0.13 \mathrm{~mm}$ on an average. 


\section{Pyrene testudinaria tylerae (Griffith \& Pidgeon)}

(Pl. XVII, fig. 18)

Faecal rods of the present species vary in colour from pale bluish grey to brown or to chocolate. They are somewhat depressed to show an oval section. The consistency is loose and soft. In an animal with about $2.0 \mathrm{~cm}$ long shell, the pellets are $0.37-0.64 \mathrm{~mm}$ in breadth.

\section{Niotha livescens (PHILIPPI)}

Pellets are shed in a rod of the loose consistency. The colour varies from light brown to yellowish white. They are loosely packed with fine and well-digested materials mixed with mucoid substance. The breadth of the pellets from an animal with a shell $1.9 \mathrm{~cm}$ alt. fluctuates between 0.46 and $1.00 \mathrm{~mm}$.

\section{Reticunassa fratercula (DUNKER)}

Pellets of this species are produced in short rods with a round section. The superficial consistency is fine and homogeneous, and the colour is greyish green. The pellets shed by an animal with a $1.55 \mathrm{~cm}$ long shell is $0.22 \mathrm{~mm}$ thick across.

\section{Pisania (Japeuthria) ferrea (REEve)}

(Pl. XVII, fig. 16)

Faecal rods are rather irregular in shape, somewhat gelatinous in consistency, and seemingly encased in capsules. They are composed of rather coarse matters mixed with a large amount of gelatinous matter and coloured greenish yellow. The breadth of rods varies grealty from part to part, but in the main $0.60-0.86 \mathrm{~mm}$.

\section{Strigatella scutulata (GMELIN)}

Faeces of this species are without any definite shape and light greenish brown in colour. They are usually voided together with a large amount of mucus. They are composed almost of fully digested materials, probably of an animal origin, mixed with a small amount of sand grains and spicules.

\section{Baryspira albocallosa (LIScHKE)}

Faecal filaments of this species are quite irregular in outline. They are light brownish green in colour, very loose in consistency, and formed of indeterminable 
fine particles mingled with some undigested fragmentary pieces and a large amount of mucoid matter.

\section{Noditerebra (Diplomeriza) evoluta (Deshayes)}

Pellets are emitted in short rods or in elongate ellipsoids $0.09 \times 0.36 \mathrm{~mm}$ in size. They are coarse in texture and light olivaceous in colour.

\section{Strigopupa strigosa (Gould)}

Pellets are rod-shaped and gelatinous in consistency. In an animal with a $0.9 \mathrm{~cm}$ long shell the pellets average $0.51 \mathrm{~mm}$ thick across.

\section{Acteocina (Tornatina) decorata (PILSBRY)}

Faecal rods of this species are very soft, fine in consistency, and light greyish green in colour. They are usually voided together with a considerable amount of mucus. The breadth of pellets from an animal with a $0.8 \mathrm{~cm}$ long shell fluctuates between 0.31 and $0.33 \mathrm{~mm}$.

\section{Siphonaria sirius PILSBRY}

Pellets are normally produced in a long continuous rod of the gelatinous consistency. They are coarse in texture, smoothly surfaced, and yellowish chocolate to yellowish white in colour according to the kind of food taken. In an animal with a $1.2 \mathrm{~cm}$ long shell, the average breadth of pellets is $0.36 \mathrm{~mm}$.

\section{Glossodoris festiva (A. Adams)}

The pellets of this species are considered to be normally in the form of a cylindric rod, though the examined animal emitted the faeces very irregular and flocculent in outline, which might probably be atypical ones. They are made of rather coarse materials mixed with a considerable amount of gelatinous substance.

\section{Homoiodoris japonica BERGH}

$$
\text { (Pl. XVII, fig. 19) }
$$

Faecal pellets are formed in a cylindric rod and marked with obscure and irregular transverse constrictions on the surface. They are loosely packed with somewhat olivaceous coarse materials mixed with mucoid matter. Starved animals tend to produce more flocculent and colourless pellets sparsely containing finely particulated organisms. 


\section{Gastropteron bicornutus ВАBA \& Токіока}

(Pl. XVII, fig. 20)

This species produces oval pellets of coarse texture. They are rounded at one end but obtusely pointed at the other, and yellowish pink in colour. The breadth of pellets shed by an examined animal fluctuates between 0.22 and $0.46 \mathrm{~mm}$.

\section{Fissidentalium vernedei (SOWERBY)}

(Pl. XVII, fig. 21)

Pellets are discharged in short rods and with a coarse and sandy appearance. They are bright greenish yellow in colour, rather loose and fragile in consistency, and built of unidentified minute particles mixed with broken pieces of foraminiferous shells. The breadth of pellets fluctuates between 0.26 and $0.35 \mathrm{~mm}$ in an animal with a $6.75 \times 0.66 \mathrm{~cm}$ shell.

\section{Graphtacme buccinulum GoulD}

Pellets are flocculent and gelatinous in consistency. They are translucent and formed mostly of a large amount of viscous matter containing well-digested fine particles. Pellets average $0.15 \mathrm{~mm}$ thick across.

\section{Sepiola sp.}

(Pl. XVII, fig. 22)

The faeces of this species varies from rod to constricted rod in shape or rarely are flocculent in appearance. They are coarse in texture on the surface, yellowish white in colour, and average $0.46 \mathrm{~mm}$ thick across in an animal $1.75 \mathrm{~cm}$ in mantlelength.

40. Callistoctopus arakawai Iw. TAKI

(Text-fig. 4)

Faecal rods of this rare octopus are built of constituent rodlets 1 to $2 \mathrm{~mm}$ in breadth. They are irregularly marked on the surface and made of somewhat coarse materials. The colour varies greatly from greysih white to deep grey or to yellowish chocolate. In an animal $114.5 \mathrm{~cm}$ in length, the faecal rods fluctuate between 3.0 and $3.5 \mathrm{~mm}$ thick across. 


\section{EXPLANATION OF PLATES XVI-XVII}

Plate XVI. Faecal pellets of Polyplacophora and Gastropoda.

1. Placiphorella sp.

2. Ischnochiton comptus forma isaoi Iw. TAKI

3. Scutus sinensis (BLAinville) a. ventral view, b. cross section

4. Conotalopia musiva (Gould) c. dorsal view, d. lateral view, e. ventral view, f. cross section

5. Hybochelus lyrata (PiLsBRY) g. dorsal view, h. cross section

6. Stomatella liniricula (A. AdAms) i. cross section, j. dorsal view, $\mathrm{k}$. ventral view.

7. Kurosioia cingulifera (SOWERBY)

8. ?Cerithidea ornata A. AdAMs

9. Proclava kochi (PhilipPI)

10. Crepidula gravispinosa Kuroda \& HaBE

11. Syphopatella walshi (REEve)

Plate XVII. Faecal pellets of Gastropoda, Scaphopoda and Cephalopoda.

12. Donaxander vittatus japonicus (REEve) 1. constituent pellets

13. Niso hizenensis Kuroda \& HABE

14. Praterato callosa (Adams \& ReEve)

15. Evenaria japonica (SCHILdER)

16. Pisania ferrea (REEve)

17. Latiaxis pagodus (A. AdAMs)

18. Pyrene testudinaria tylerae (GRIfFITH \& Pidgeon) m. dorsal view, $\mathrm{n}$. cross: section

19. Homoiodoris japonica BERGH

20. Gastropteron bicornutus BABA \& ToKIOKA

21. Fissidentalium vernedei (SoWERBY)

22. Sepiola sp. 
Publ. Seto Mar. Biol. Lab., XVI (2), 1968. PLATE XVI
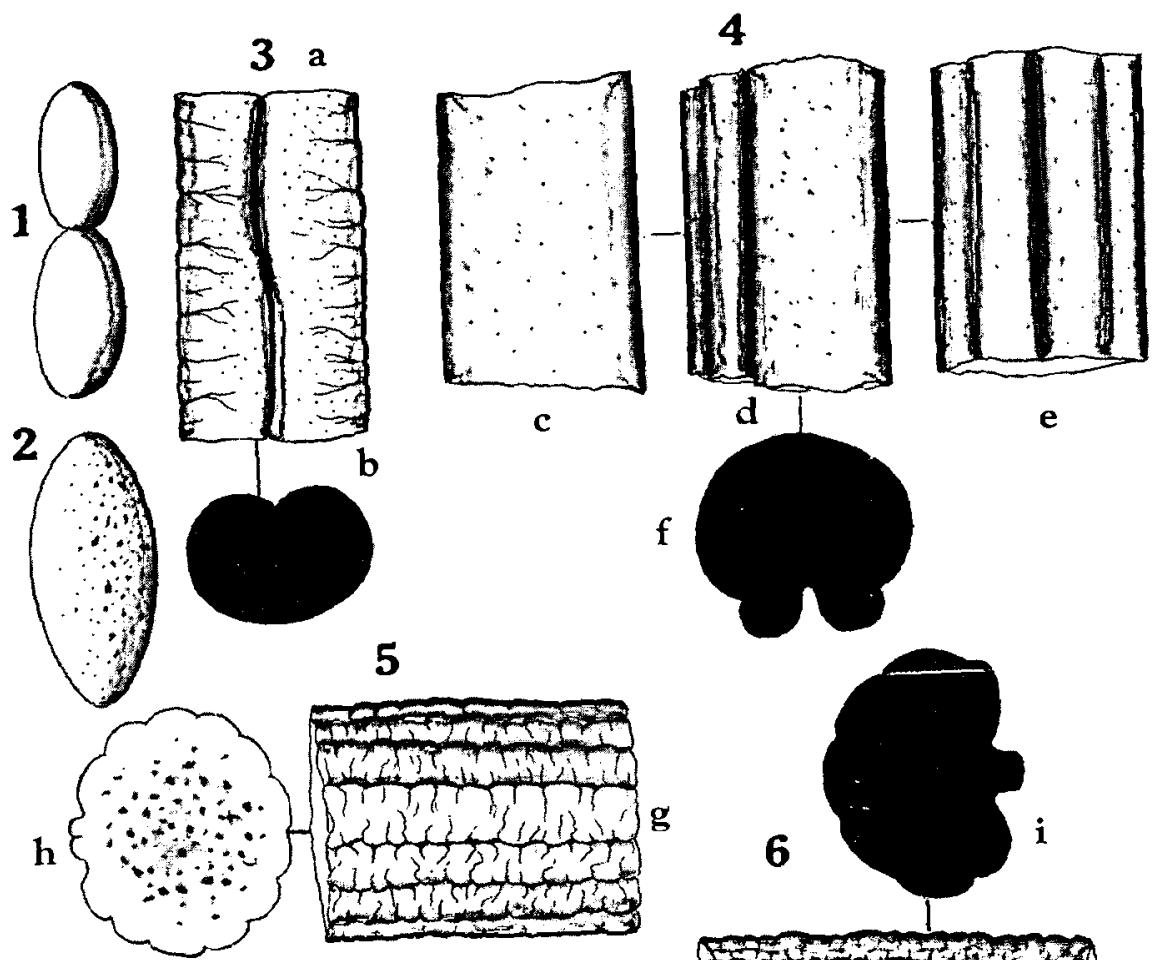

f
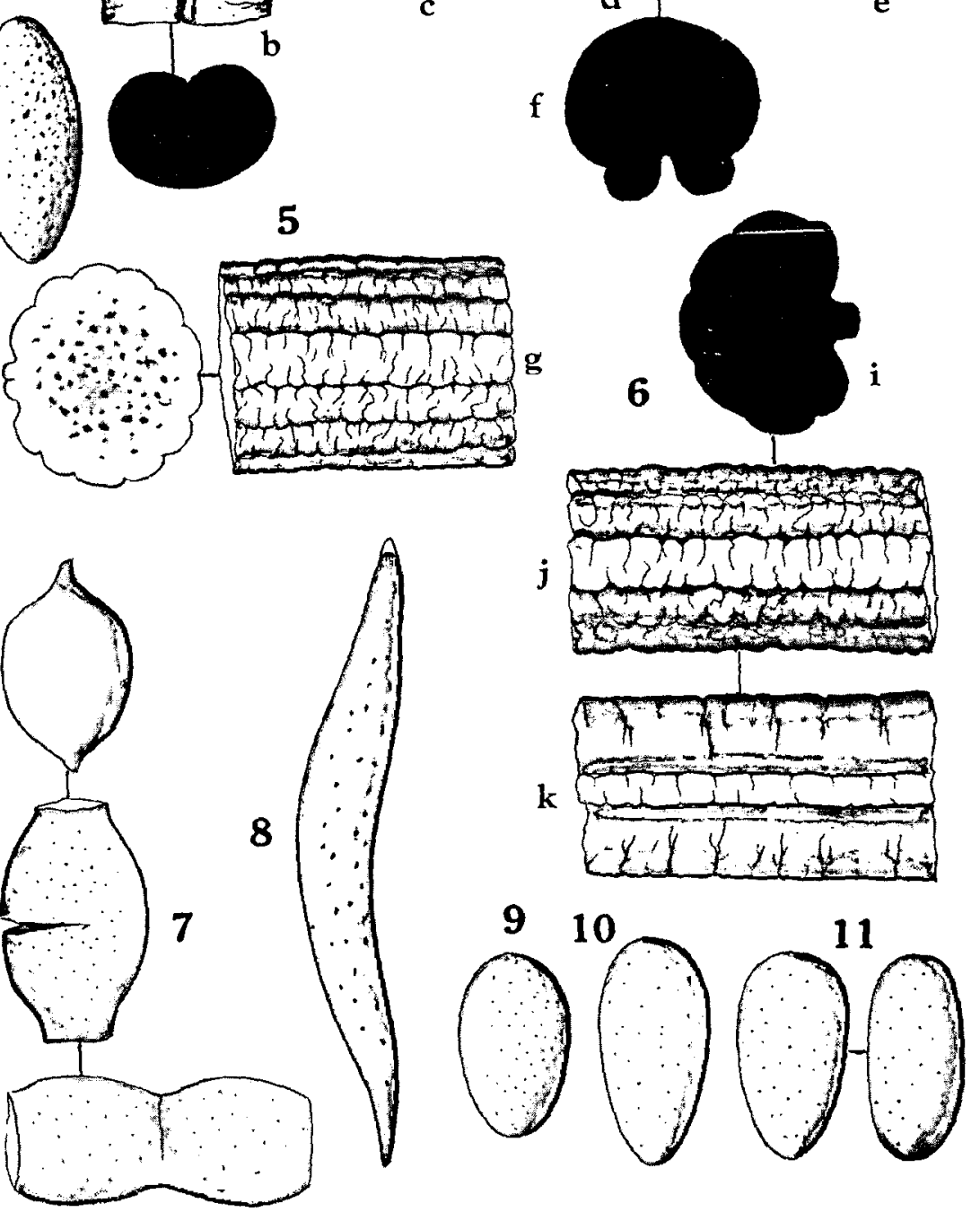

K. Y. ARakawa: Studies on Molluscan Faeces $1 I I$

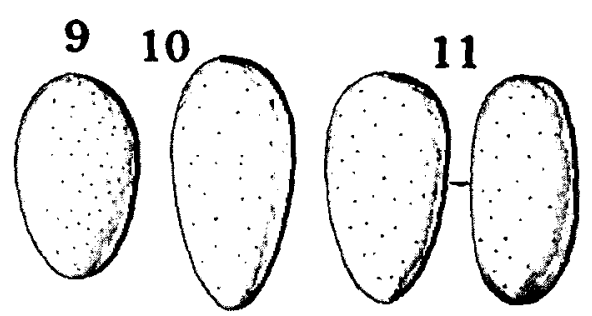

k

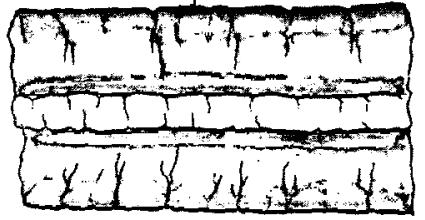


Publ. Seto Mar. Biol. Lab., XVI (2), 1968. PLATE XVII
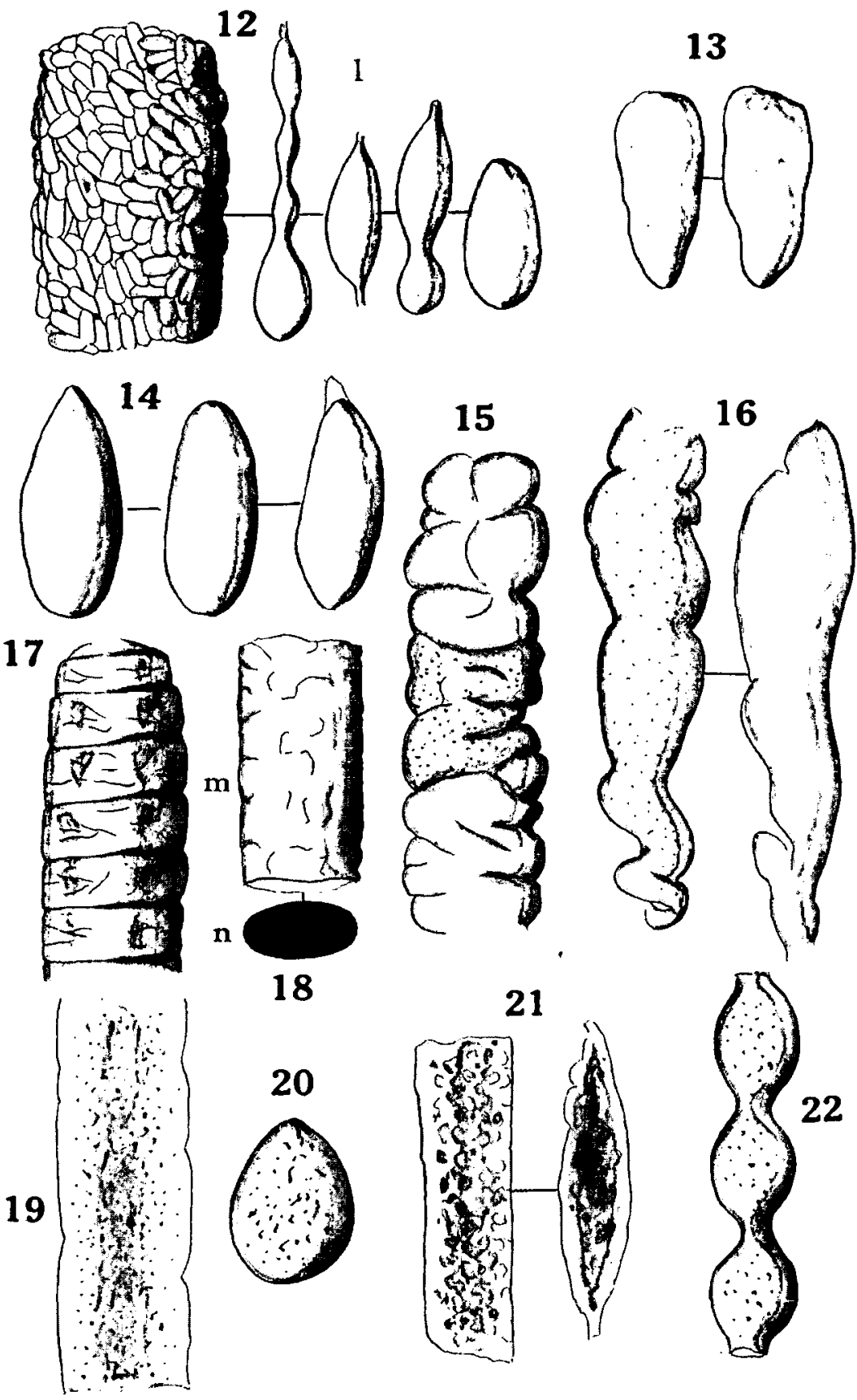

K. Y. Arakawa: Studies on Molluscan Faeces III 